\title{
Mesorhizobium caraganae sp. nov., a novel rhizobial species nodulated with Caragana spp. in China
}

Correspondence

Wen Feng Chen

chenwf@cau.edu.cn

\author{
Su Hua Guan, ${ }^{1}$ Wen Feng Chen, ${ }^{1}$ En Tao Wang, ${ }^{2}$ Yang Li Lu, ${ }^{1}$ \\ Xue Rui Yan, ${ }^{3}$ Xiao Xia Zhang ${ }^{4}$ and Wen Xin Chen ${ }^{1}$
}

${ }^{1}$ Key Laboratory of Agro-Microbial Resource and Application, Ministry of Agriculture/College of Biological Sciences, China Agricultural University, Beijing 100193, PR China
${ }^{2}$ Departamento de Microbiología, Escuela Nacional de Ciencias Biológicas, Instituto Politécnico Nacional, 11340 México D. F., Mexico
${ }^{3}$ College of Plant Protection, Shenyang Agricultural University, Shenyang 110161, PR China
${ }^{4}$ Agricultural Cultural Collection of China, Institute of Agricultural Resources and Regional Planning, Chinese Academy of Agricultural Sciences, Beijing 100081, PR China

\begin{abstract}
Five rhizobial strains representing the largest group in the genus Mesorhizobium associated with Caragana spp. in China were characterized taxonomically. Phylogenetic analysis based on 16S rRNA gene sequences indicated that these microsymbionts belonged to the genus Mesorhizobium, with Mesorhizobium tianshanense USDA $3592^{\top}$, Mesorhizobium temperatum SDW018 ${ }^{\top}$ and Mesorhizobium mediterraneum UPM-Ca36 ${ }^{\top}$ as the closest neighbours ( $\geqslant 99.5 \%$ 16S rRNA gene sequence similarity). Genotypic fingerprinting by whole-cell protein electrophoresis, DNA-DNA hybridization, comparative housekeeping sequence analysis of the atp $D, g / n / l$ and $r e c A$ genes, fatty acid profiles and a series of phenotypic and physiological tests allowed the novel group to be differentiated from all previously recognized species of the genus Mesorhizobium. This group therefore represents a novel species, for which the name Mesorhizobium caraganae sp. nov. is proposed with the type strain CCBAU $11299^{\top}$ (=LMG $24397^{\top}=$ HAMBI $2990^{\top}$ ). Cross-inoculation tests showed that strain CCBAU $11299^{\top}$ could form effective nodules on Caragana microphylla, Caragana intermedia, Glycyrrhiza uralensis, Astragalus adsurgens and Phaseolus vulgaris.
\end{abstract}

Caragana, a genus of the subfamily Papilionoideae in the Leguminosae, is a perennial leguminous shrub that is highly tolerant to drought, salt and extreme cold and grows in relatively poor or sandy, well-drained soil. In China, over 60 species have been recorded within this genus. They are often used as windbreaks to protect soils from desertification in the northern regions of China ( $\mathrm{Su}$ et al., 2005). They are also used for livestock forage and

Abbreviation: NJ, neighbour-joining.

The GenBank/EMBL/DDBJ accession number for the partial $16 \mathrm{~S}$ rRNA, atpD, recA, glnll, nodC and nifH gene sequences of Mesorhizobium caraganae sp. nov. CCBAU $11299^{\top}$ are EF149003, EU249379, EU249394, EU249384, EU130405 and EU130422, respectively.

Tables giving details of fatty acid contents and DNA-DNA relatedness of the novel strains compared with recognized species of the genus Mesorhizobium and figures showing phylogenetic trees based on the nodC and nifH genes and a phenogram derived from UPGMA analysis and SDS-PAGE analysis of whole-cell proteins of strain CCBAU $11299^{\top}$ are available as supplementary materials in IJSEM Online. as high-energy firewood. Their flowers are a good source of food for bees and their seeds are used as herbal medicines (Xiang et al., 2005).

Rhizobia are soil bacteria that fix nitrogen (diazotrophy) after becoming established inside the root nodules of legumes. Most rhizobia symbiosed with Caragana spp. growing in Liaoning Province of China have been placed within the genus Mesorhizobium (Yan et al., 2007). This genus was established by Jarvis et al. (1997) to describe rhizobia whose growth rate was slower than the fastgrowing members of the genus Rhizobium and faster than the slow-growing members of the genus Bradyrhizobium. At the time of writing, 12 species are included in the genus Mesorhizobium (for details see http://www.bacterio.cict.fr/ $\mathrm{m} / \mathrm{mesorhizobium} . \mathrm{html}$ ). In our previous studies, a group of mesorhizobia associated with Caragana spp. (designated Mesorhizobium sp. III) in the Liaoning Province of China showed unique protein and BOX-PCR patterns different from those of the recognized species of this genus (Yan et al., 2007). In this study, two strains (CCBAU $11299^{\mathrm{T}}$ and 
CCBAU 11300) representing Mesorhizobium sp. III and three additional strains (CCBAU 01502, CCBAU 01519, CCBAU 01528), isolated from Caragana intermedia in Inner Mongolia, China, a region adjacent to Liaoning Province, were studied in more detail by comparing the SDS-PAGE of whole soluble proteins, $16 \mathrm{~S}$ rRNA gene sequences, housekeeping genes (atpD, recA and $g \ln I I)$, symbiotic genes (nodC and nifH), DNA-DNA hybridization and biochemical characteristics with the recognized species of the genus Mesorhizobium. Comparisons of fatty acid profiles were also made between the novel group and the recognized species of the genus. Based on the results of this polyphasic taxonomic approach, Mesorhizobium sp. III, together with the three isolates from Inner Mongolia, formed a coherent group and thus a novel species is proposed. The strains were maintained on YMA (Vincent, 1970 ) at $4{ }^{\circ} \mathrm{C}$ for temporary storage and in $20 \%$ glycerol at $-70{ }^{\circ} \mathrm{C}$ for long-term storage.

The five novel strains and the reference strains of the genus Mesorhizobium (Table 1) were subjected to SDS-PAGE analysis of whole-cell soluble proteins. Cellular protein extracts were prepared and electrophoretic analysis was performed as described previously (Tan et al., 1997). Digitization, normalization and numerical analyses of the protein profiles were performed with the GelCompar II version 4.5 software (Applied Maths). The similarity between pairs of protein patterns was expressed by the Pearson's coefficient and a UPGMA dendrogram was constructed (Vauterin \& Vauterin, 1992). The strikingly similar protein patterns observed among the five novel strains indicated considerable homogeneity (see Supplementary Fig. S1a in IJSEM Online; the profile of strain CCBAU 11300 was the same as CCBAU 11299 and is therefore not shown in this figure). However, the isolates were not duplicates as they had been isolated from different regions and different species of Caragana (Table 1). A comparison of the protein patterns with those of other recognized species of the genus Mesorhizobium revealed that none of the protein profiles of the recognized strains were highly similar to those of the novel group (only $67 \%$ similarity, see Supplementary Fig. S1b in IJSEM Online).

Fatty acid profiling is a popular method for characterizing the microbial communities of natural systems (Schutter \& Dick, 2000) and is a useful tool for the identification of root-nodule bacteria (Tighe et al., 2000). In this study, all the mesorhizobia were grown on YMA medium for $72 \mathrm{~h}$ at $28{ }^{\circ} \mathrm{C}$ and then approximately $40 \mathrm{mg}$ of the well-grown cells was harvested. Fatty acid methyl esters were prepared and separated using a previously described method (Sasser, 1990) and identified with the MIDI Sherlock Microbial Identification System. The cellular fatty acid profiles of the novel group and related species of the genus Mesorhizobium are shown in Supplementary Table S1 (available in IJSEM Online). The novel group could be assigned to the genus Mesorhizobium because they lacked $20: 3 \omega 6,9,12 c$ and summed feature $2(12: 0$, unknown ECL $10.928,16: 1$ iso $1 / 14: 03-\mathrm{OH})$ and possessed $17: 0$ iso fatty acids (Tighe et al., 2000; Wang et al., 2007). The

Table 1. Strains used in this study and relevant information

\begin{tabular}{|c|c|c|c|}
\hline Strain & Host plant & Geographical origin & Reference \\
\hline \multicolumn{4}{|l|}{ Mesorhizobium caraganae sp. nov. } \\
\hline CCBAU $11299^{\mathrm{T}}$ & Caragana microphylla & Liaoning, China & Yan et al. (2007) \\
\hline CCBAU 01502 & Caragana intermedia & Inner Mongolia, China & This study \\
\hline CCBAU 01519 & Caragana intermedia & Inner Mongolia, China & This study \\
\hline CCBAU 01528 & Caragana intermedia & Inner Mongolia, China & This study \\
\hline M. albiziae CCBAU $61158^{\mathrm{T}}$ & Albizia kalkora & Sichuan, China & Wang et al. (2007) \\
\hline M. loti NZP $2213^{\mathrm{T}}\left(=\mathrm{LMG} 6125^{\mathrm{T}}=\mathrm{USDA} 3471^{\mathrm{T}}\right)$ & Lotus corniculatus & New Zealand & Jarvis et al. (1997) \\
\hline M. plurifarium LMG $11892^{\mathrm{T}}\left(=\mathrm{ICMP} 13640^{\mathrm{T}}\right)$ & Acacia senegal & Senegal & de Lajudie et al. (1998) \\
\hline $\begin{array}{l}\text { M. amorphae ACCC } 19665^{\mathrm{T}}\left(=\mathrm{ICMP} 15022^{\mathrm{T}}\right. \\
\left.=\mathrm{LMG} 18977^{\mathrm{T}}\right)\end{array}$ & Amorpha fruticosa & Beijing, China & Wang et al. (1999) \\
\hline $\begin{array}{l}\text { M. chacoense LMG } 19008^{\mathrm{T}}\left(=\operatorname{Pr}-5^{\mathrm{T}}=\mathrm{ICMP}\right. \\
\left.14587^{\mathrm{T}}\right)\end{array}$ & Prosopis alba & Argentina & Velázquez et al. (2001) \\
\hline M. mediterraneum USDA $3392^{\mathrm{T}}\left(=\mathrm{UPM}-\mathrm{Ca}-36^{\mathrm{T}}\right)$ & Cicer arietinum & Spain & Nour et al. (1995) \\
\hline M. septentrionale SDW014 ${ }^{\mathrm{T}}$ & Astragalus adsurgens & Liaoning, China & Gao et al. (2004) \\
\hline M. temperatum SDW018 ${ }^{\mathrm{T}}$ & Astragalus adsurgens & Liaoning, China & Gao et al. (2004) \\
\hline $\begin{array}{l}\text { M. tianshanense CCBAU } 3306^{\mathrm{T}}\left(=\mathrm{USDA} 3592^{\mathrm{T}}\right. \\
=\mathrm{A}-1 \mathrm{BS})\end{array}$ & Glycyrrhiza pallidiflora & Xinjiang, China & Chen et al. (1995) \\
\hline
\end{tabular}


strains of the novel group differed from Mesorhizobium mediterraneum by their much higher concentrations of $16: 0$, summed feature 4 (17:1 iso I/anteiso $\mathrm{B}$ and/or $17: 1$ anteiso B/iso I), summed feature $8(18: 1 \omega 7 c$ and/or $18: 1 \omega 6 c$ ) and lower concentrations of 11-methyl $18: 1 \omega 7 c$, 19:0 cyclo $\omega 8 c$. The novel group differed from Mesorhizobium temperatum by the presence of $15: 0$ iso, $17: 0$,

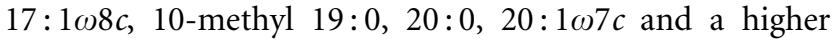
concentration of summed feature $8 \quad(18: 1 \omega 7 c$ and/or $18: 1 \omega 6 c)$. When compared with Mesorhizobium tianshanense, the members of the novel group possessed 11-methyl 18: $1 \omega 7 c, 19: 0$ cyclo $\omega 8 c$ and summed feature 8 but lacked of summed feature $7(18: 1 \mathrm{cll} / \mathrm{tg} / \mathrm{t} 6 \mathrm{and} / \mathrm{or} 18: 1$ trans 9/t6/c11). The novel strains differed from Mesorhizobium septentrionale in that they lacked $16: 1 c 9,18: 1 c 9$, unknown fatty acid (ECL19.368), summed feature 5 (17:1 iso $\mathrm{I} /$ anteiso $\mathrm{B}$ and/or $17: 1$ anteiso $\mathrm{B} / \mathrm{I} \mathrm{I}$ ) and summed feature 7 but did contain 11-methyl $18: 1 \omega 7 c, 19: 0$ cyclo $\omega 8 c$, summed feature $3(16: 1 \omega 7 c / 16: 1 \omega 6 c$ and/or $16: 1 \omega 6 c l$ $16: 1 \omega 7 c$ ) and summed feature 8 . The novel strains differed from other recognized Mesorhizobium species by containing higher amounts of summed feature 8 , lower amounts of 11-methyl $18: 1 \omega 7 c$ and lacking fatty acids of summed features 5 and 7 .

The 16S rRNA gene was amplified and sequenced for the five novel strains isolated from Caragana spp. using primers P1 and P6 according to the technique of Tan et al. (1997). The sequences were aligned with those of related species of the genus Mesorhizobium using the CLUSTAL W program from the MEGA 4.0 software package (Tamura et al., 2007). Aligned sequences were analysed using MEGA to produce a Jukes-Cantor distance (Jukes \& Cantor, 1969) and to construct an optimal unrooted tree using the neighbour-joining method (Saitou \& Nei, 1987). The robustness of the tree topology was calculated from bootstrap analysis using 1000 replications of the sequences (Felsenstein, 1985). All five novel strains had identical 16S rRNA gene sequences and were closely related to $M$. temperatum SDW018 ${ }^{\mathrm{T}}$, M. mediterraneum UPM-Ca $36^{\mathrm{T}}$ and $M$. tianshanense USDA $3592^{\mathrm{T}}$ (Fig. 1a), with more than $99.5 \%$ similarity between strain CCBAU $11299^{\mathrm{T}}$ and these three species.

Housekeeping genes ( $a t p D, g \ln I, g \ln I I, r e c A, d n a K$ etc.) have been used in taxonomic and phylogenetic studies of rhizobia (Gao et al., 2004; Gaunt et al., 2001; Ghosh \& Roy, 2006; Parker, 2004; Stepkowski et al., 2003; Turner \& Young, 2000; Vinuesa et al., 2005; Wernegreen \& Riley, 1999; Wang et al., 2007). Most recently, multilocus sequence analysis (MLSA) of ten housekeeping genes was performed and the results were compared with data from DNA-DNA hybridization experiments for 34 representatives of the genus Ensifer (Martens et al., 2008). The results obtained by Martens et al., 2008) indicated that sequencing of housekeeping genes was superior to DNA-DNA hybridization for the assessment of genetic relatedness between species of the genus Ensifer. To investigate the genomic diversity of the root nodule isolates from
Caragana spp., we sequenced the variable regions of three housekeeping genes, atpD (gene encoding the ATP synthase $\beta$-subunit), recA (homologous recombination protein A) and glnII (glutamine synthetase gene) and compared them with the same genes from recognized species of the genus Mesorhizobium. In this study, PCR amplification and sequencing of partial atpD and recA genes were undertaken according to Gaunt et al. (2001) and a $600 \mathrm{bp}$ intragenic fragment of $g \ln I I$ was amplified according to Turner \& Young (2000). The five novel Mesorhizobium strains had identical partial atpD sequences and shared $94.5 \%$ sequence similarity with M. septentrionale SDW014 ${ }^{\mathrm{T}}$. Strain CCBAU $11299^{\mathrm{T}}$ had $95.6 \%$ gene sequence similarity to $M$. tianshanense and $94 \%$ similarity to $M$. septentrionale SDW $014^{\mathrm{T}}$ for the recA sequence. In the analysis of the partial $g \ln I I$ gene, the five novel strains differed by only 2 or $4 \mathrm{bp}$ and showed similarity levels of $\leqslant 92.7 \%$ with the type strains of recognized species of the genus Mesorhizobium. Neighbour-joining (NJ) trees constructed with the same methods as used for the $16 \mathrm{~S}$ rRNA gene analysis are shown in Fig. 1b, c and d based on the respective sequences. The groupings and precise branching patterns for the three different genes were not always congruent with those found for the 16S rRNA gene sequence tree, and the bootstrap values were not always high. This may be due to the occurrence of lateral gene transfer events and the fact that fewer taxa were included for the construction of the phylogenetic trees. When further highly similar strains were added to the analysis, as studied in this research, the five novel strains clustered very closely together in each tree and the branches were supported by high bootstrap values ranging from 96 to $100 \%$ (Fig. 1a, b, c and d).

The symbiotic genes (nod and nif) are required for the successful establishment of highly specific symbiosis between rhizobia and legumes and are important determinants of rhizobial host specificity. Therefore, comparisons of these symbiotic genes may reveal the host ranges of rhizobia. In this study, partial sequences of the symbiotic genes nodC and nifH for the five novel strains were amplified by using the previously described primers (nodCF and nodCI, nifHF and nifHI) and PCR conditions as described by Laguerre et al. (2001). The nodC gene sequences for the five strains isolated from Caragana were closely related, with sequence similarities ranging from 99 to $100 \%$. In the NJ tree (see Supplementary Fig. S2a in IJSEM Online), the five strains were closely placed to the type strains of $M$. tianshanense, $M$. temperatum and $M$. septentrionale and had $>96.7 \%$ nodC gene sequence similarity with these strains. The nifH gene sequence of the novel strains isolated from Caragana spp. showed sequence similarities that ranged from 98 to $100 \%$ and showed $>91.2 \%$ sequence similarity to those of $M$. tianshanense, M. temperatum and M. septentrionale (see Supplementary Fig. S2b in IJSEM Online).

The high similarities between the symbiotic genes from the mesorhizobia isolated from Caragana spp. and the type 


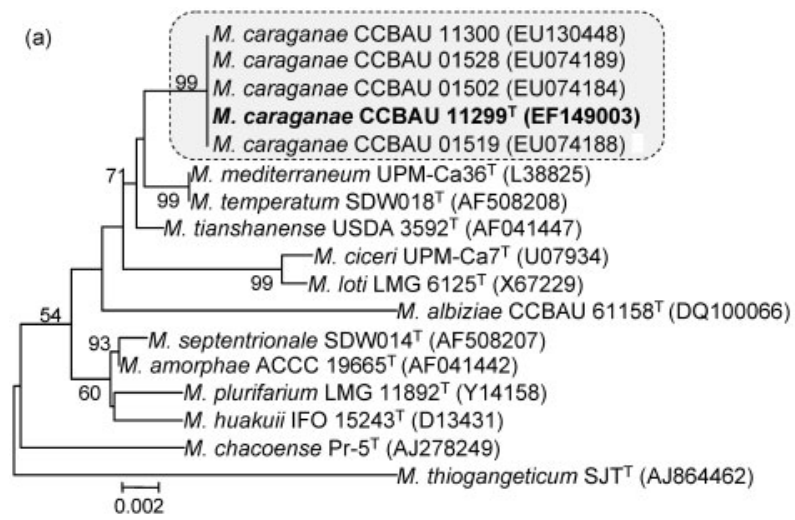

(c)

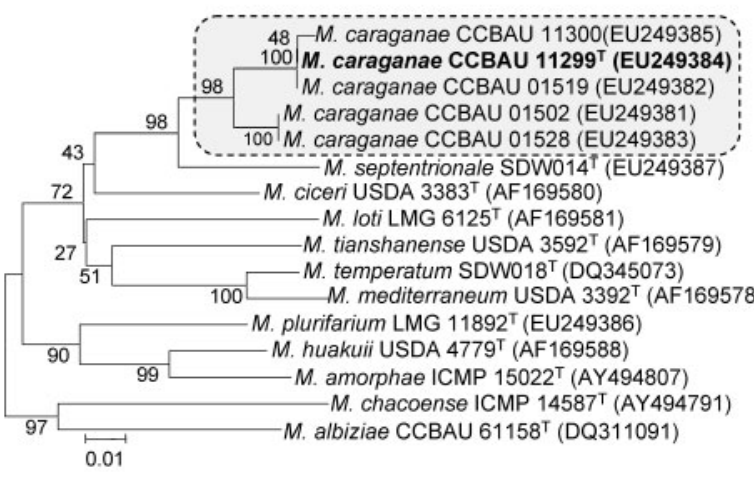

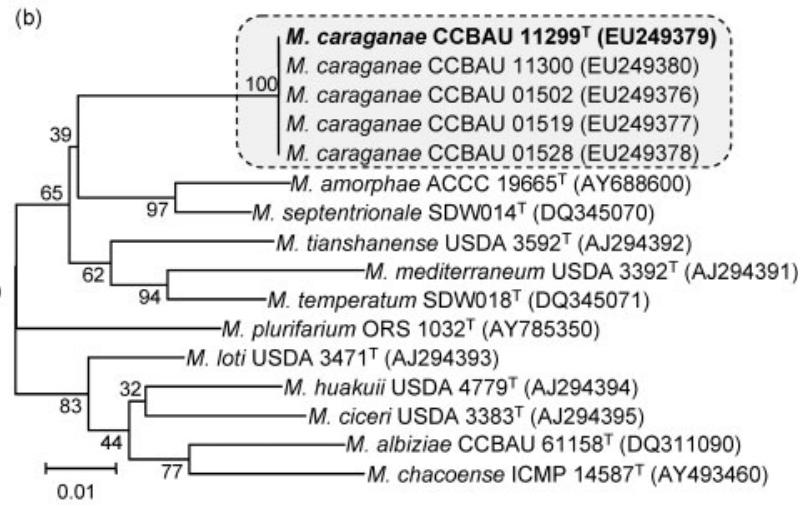

(d)

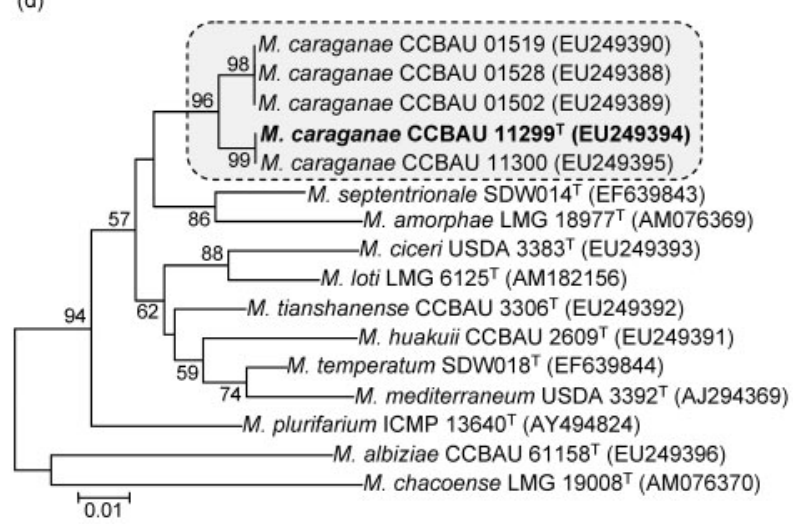

Fig. 1. Comparison of $16 \mathrm{~S}$ rRNA (a), atpD (b), gln/l (c) and $\operatorname{rec} A(\mathrm{~d})$ gene phylogenies, showing the relationships among the novel group (Mesorhizobium caraganae sp. nov.) (hatched and framed) and recognized species of the genus Mesorhizobium. Trees were constructed by the neighbour-joining method with a Jukes-Cantor distance matrix. Bootstrap values (\%) are based on 1000 replications and are shown at each node. Bars, expected number of changes per site.

strains of $M$. temperatum, $M$. septentrionale and $M$. tianshanense demonstrated that these strains may have common host ranges, as suggested by Laguerre et al. (2001). Strains of M. septentrionale and M. temperatum were originally isolated from nodules of Astragalus adsurgens in Liaoning (Gao et al., 2001), from where the Caragana microsymbionts were isolated in this study (Yan et al., 2007). M. tianshanense A-1BS ${ }^{\mathrm{T}}$ was isolated from Glycyrrhiza pallidiflora (Chen et al., 1995) in the Xinjiang province of China, a region about $5000 \mathrm{~km}$ away from Liaoning. However, two strains (032B and 91X11) within the species $M$. tianshanense were isolated from nodules of Caragana polourensis, while strain $\mathrm{A}-1 \mathrm{BS}^{\mathrm{T}}$ could form effective nodules with Caragana polourensis (Chen et al., 1995). Therefore, the high sequence similarities of the symbiotic genes, especially for the nod genes, might indicate that these bacteria could share their hosts, as suggested by Laguerre et al. (2001). To test whether the Caragana mesorhizobia shared the same hosts with these three species, cross-inoculation between these strains and the recognized Mesorhizobium species and their original hosts was performed. Seed treatment and inoculation of
Caragana microphylla and Astragalus adsurgens were conducted using the standard method of Vincent (1970). Since seeds of the original host plant, Glycyrrhiza pallidiflora, were not available, we used Glycyrrhiza uralensis as the test plant. Seeds of Glycyrrhiza uralensis were first immersed in concentrated sulfuric acid for $4 \mathrm{~h}$ before surface-sterilization. Seedlings inoculated with different strains were grown in a greenhouse under natural daylight for 6 weeks. The non-inoculated seedlings were used as controls and were cultured under the same conditions. The results confirmed that each of the five novel strains from Caragana spp. and the three type strains (M. tianshanense, M. temperatum and M. septentrionale) could form effective nodules on Glycyrrhiza uralensis, Caragana microphylla, Caragana intermedia and Astragalus adsurgens. The representative strain, CCBAU $11299^{\mathrm{T}}$, of the novel Mesorhizobium group was also used for crossnodulation tests with another 11 legume species. The results showed that only Phaseolus vulgaris, a promiscuous host to many kinds of rhizobia, could be nodulated with CCBAU $11299^{\mathrm{T}}$, while no nodules were found on seedlings of Glycine max, Trifolium pratense, Medicago sativa, Pisum 
sativum, Melilotus albus, Amorpha fruticosa, Lespedeza cuneata, Dunbaria rotundifolia, Vigna radiata and Vicia septum. The nodulation spectra of strain CCBAU $11299^{\mathrm{T}}$ were different from those of strains $M$. tianshanense USDA $3592^{\mathrm{T}}$, M. septentrionale SDW014 ${ }^{\mathrm{T}}$ and M. temperatum SDW $018^{\mathrm{T}}$, indicating that the novel group of isolates could have unique host-specific genes.

For the determination of the DNA base composition and DNA-DNA relatedness, total DNA was extracted from each strain using the method of Marmur (1961). Using the thermal denaturation method (Marmur \& Doty, 1962) and Escherichia coli $\mathrm{DH} 5 \alpha$ as a standard, the DNA G $+\mathrm{C}$ content of strain CCBAU $11299^{\mathrm{T}}$ was found to be $59.7 \mathrm{~mol} \%\left(T_{\mathrm{m}}\right)$. This value was within the range reported for members of the genus Mesorhizobium (59-64 mol\%; Jarvis et al., 1997). DNA relatedness values between the strains of the novel group and the most closely related Mesorhizobium species were determined using the spectrophotometric method of De Ley (1970). The DNA-DNA relatedness values between CCBAU $11299^{\mathrm{T}}$ and recognized Mesorhizobium species ranged from 7 to $35 \%$ (see Supplementary Table S2 in IJSEM Online) and suggested that the novel group represented a novel genomic species in the genus Mesorhizobium.

The phenotypic features of the novel group of isolates were determined and compared with those of related species of the genus Mesorhizobium according to the method described by Gao et al. (1994). The tested features included the utilization of sole carbon and nitrogen sources, resistance to antibiotics and tolerance of $\mathrm{NaCl}$, and the $\mathrm{pH}$ and temperature ranges for growth (Gao et al., 1994). The distinctive features of the novel group are shown in Table 2 and further features are presented in the description of the novel species.

Based on the results obtained in this study, we believe that the five new strains represent a novel species in the genus Mesorhizobium. This species could be differentiated by SDS-PAGE of cellular proteins, fatty acid profiles, phenotypic characteristics, DNA-DNA relatedness and by the sequencing of the atpD, glnII, recA, nodC and nifH genes. The name Mesorhizobium caraganae sp. nov. is proposed for the most abundant rhizobial group, group III, represented by the five novel strains associated with Caragana spp. growing in the Liaoning Province of China.

\section{Description of Mesorhizobium caraganae sp. nov.}

Mesorhizobium caraganae (ca.ra.ga'na.e. N.L. gen. n. caraganae of Caragana, a genus of leguminous plants, referring to the rhizobium isolated from root nodules of Caragana spp.).

Gram-negative, aerobic, motile, non-spore-forming rods, $0.5 \mu \mathrm{m}$ wide by $2-3 \mu \mathrm{m}$ long. Colonies on yeast mannitol

Table 2. Distinctive features of strains of Mesorhizobium caraganae sp. nov. and recognized species of the genus Mesorhizobium

Strains: 1, M. ciceri USDA $3383^{\mathrm{T}}$; 2, M. chacoense LMG $19008^{\mathrm{T}} ; 3$, M. huakuii CCBAU $2609^{\mathrm{T}} ; 4$, M. albiziae CCBAU 61158 ${ }^{\mathrm{T}}$; 5, M. amorphae ACCC

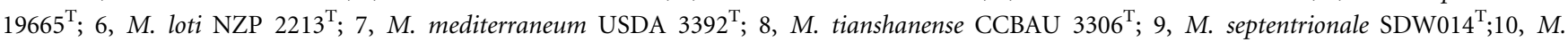
temperatum SDW018 ${ }^{\mathrm{T}}$; 11, M. plurifarium LMG $11892^{\mathrm{T}}$; 12, M. caraganae sp. nov. CCBAU 11299 ${ }^{\mathrm{T}}$; 13, M. caraganae CCBAU 11300; 14, M. caraganae CCBAU 01502; 15, M. caraganae CCBAU 01519; 16, M. caraganae CCBAU 01528. +, Growth or resistant;-, no growth or sensitive; ND, not detected or cannot be distinguished.

\begin{tabular}{|c|c|c|c|c|c|c|c|c|c|c|c|c|c|c|c|c|}
\hline Characteristic & 1 & 2 & 3 & 4 & 5 & 6 & 7 & 8 & 9 & 10 & 11 & 12 & 13 & 14 & 15 & 16 \\
\hline \multicolumn{17}{|c|}{ Utilization as sole carbon source: } \\
\hline D-Arabinose & + & ND & ND & - & - & - & - & - & - & + & + & + & + & + & + & + \\
\hline Inulin & + & + & + & + & - & - & - & - & + & + & + & + & + & + & + & + \\
\hline Dextrin & - & - & + & - & - & - & - & - & + & - & - & + & + & + & + & + \\
\hline Dulcitol & - & - & - & - & - & - & - & - & + & - & - & - & - & - & - & - \\
\hline meso-Erythritol & + & - & - & - & + & - & - & - & + & + & - & + & + & + & + & + \\
\hline D-Amygdalin & + & - & - & - & - & - & - & - & + & - & - & + & + & + & + & + \\
\hline Inositol & + & + & + & + & + & + & + & + & + & + & + & + & + & + & + & + \\
\hline D-Fructose & + & - & + & - & + & + & + & + & - & - & + & + & + & + & + & + \\
\hline Sodium DL-malate & + & - & + & + & + & + & - & - & - & - & + & + & + & - & + & + \\
\hline Maltose & + & - & + & - & + & + & + & - & + & - & + & + & + & + & + & + \\
\hline Melibiose & - & - & - & - & + & - & - & - & - & - & - & - & - & + & - & - \\
\hline Sodium pyruvate & - & - & - & - & - & - & - & - & + & - & - & + & - & - & + & - \\
\hline Raffinose pentahydrate & - & + & + & + & - & - & - & - & + & + & + & - & - & + & + & + \\
\hline L-Rhamnose & + & - & + & - & - & + & + & - & + & + & + & + & + & + & + & + \\
\hline Salicin & - & - & - & - & - & - & - & - & - & - & + & - & - & - & - & - \\
\hline D-Ribose & + & - & + & - & - & - & - & - & + & + & + & + & + & + & + & + \\
\hline Sodium acetate & + & - & + & - & - & - & - & - & + & + & + & + & + & + & + & + \\
\hline Sodium citrate & - & - & - & - & + & - & - & - & - & - & + & - & - & + & + & + \\
\hline
\end{tabular}


Table 2. cont.

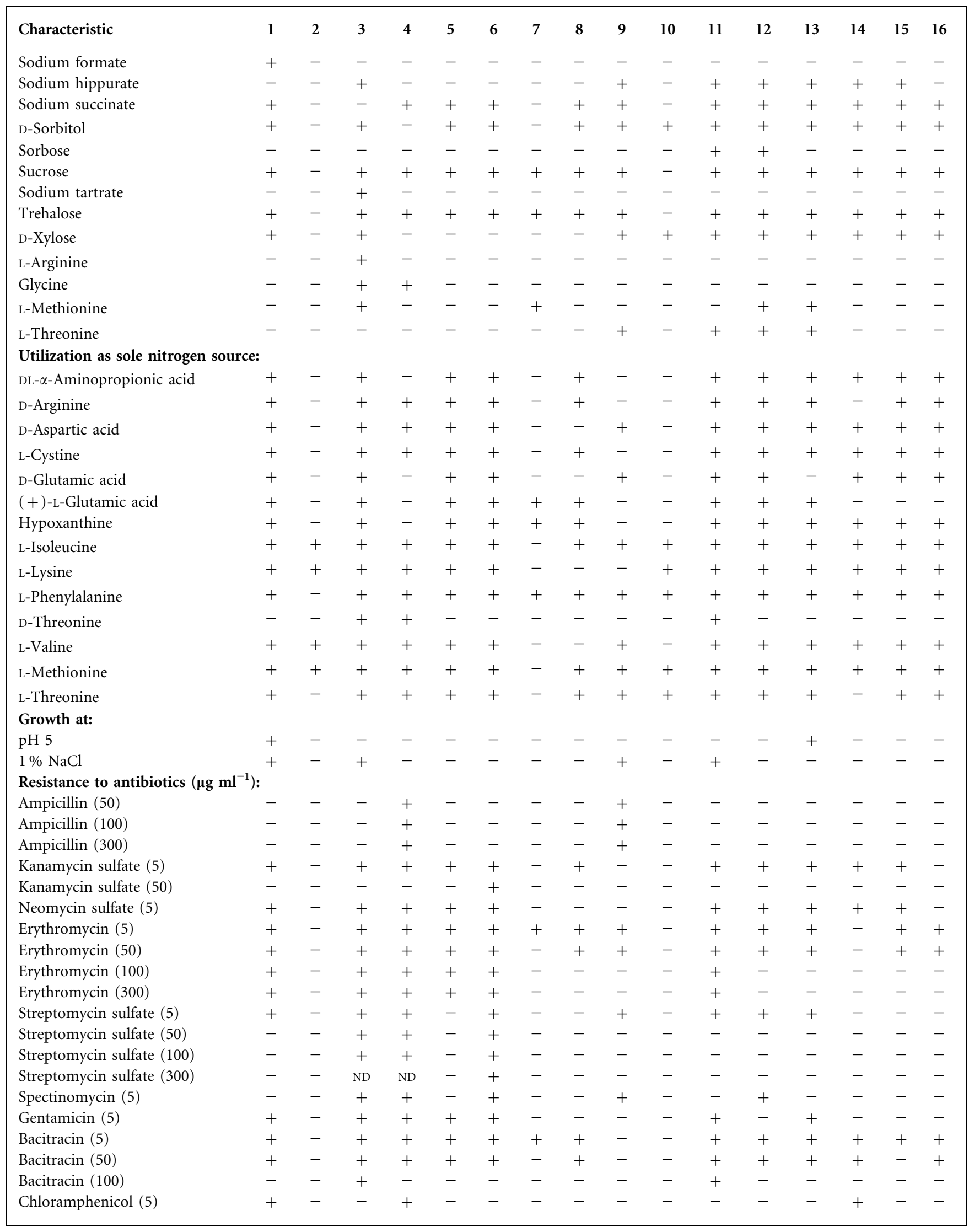


agar (YMA) plates are circular, convex, white, opaque and usually $1-2 \mathrm{~mm}$ in diameter within 5-7 days incubation at $28{ }^{\circ} \mathrm{C}$. The generation time is about $8 \mathrm{~h}$ in PY broth at $28{ }^{\circ} \mathrm{C}$. The optimum temperature and $\mathrm{pH}$ for growth are $28{ }^{\circ} \mathrm{C}$ and $\mathrm{pH} 7$, respectively. The maximum temperature for growth is $40{ }^{\circ} \mathrm{C}$. Able to survive being heated at $60{ }^{\circ} \mathrm{C}$ for $10 \mathrm{~min}$. Catalase-positive, but oxidase-negative. The type strain can utilize D-galactose, glucose, inositol, Dmannose and the sugars listed in Table 2 as sole carbon sources. Able to utilize almost all the tested sole nitrogen sources except for D-threonine. Does not utilize adipic acid, calcium gluconate, calcium malonate, melezitose, sodium D-gluconate, soluble starch, syringic acid, vanillic acid, DL-asparagine or L-proline as a sole carbon source. Resistance and sensitivity to antibiotics is shown in Table 2 and is also sensitive to $\left(\mu \mathrm{g} \mathrm{ml}^{-1}\right)$ kanamycin sulfate (100), neomycin sulfate (50), spectinomycin (50), gentamicin (50), bacitracin (300), tetracycline hydrochloride (5), chloramphenicol (50). Synthesizes the following fatty acids (full details are given in Supplementary Table S1 in IJSEM Online) : 13:0 2-OH, 14:0, 15:1 isoG, $16: 0,17: 0,17: 0$ iso, $18: 0,11$-methyl $18: 1 \omega 7 c, 18: 1 \omega 9 c, 19: 0$ cyclo $\omega 8 c$, $20: 0,20: 1 \omega 7 c$, summed feature $1(15: 1$ iso $\mathrm{H} / 13: 03-\mathrm{OH}$ and/or 13:0 3-OH/15:1 i $\mathrm{H})$, summed feature 3 $(16: 1 \omega 7 c / 16: 1 \omega 6 c$ and/or $16: 1 \omega 6 c / 16: 1 \omega 7 c)$, summed feature 4 (17: 1 iso I/anteiso $\mathrm{B}$ and/or 17: 1 anteiso $\mathrm{B} /$ iso I) and summed feature $8(18: 1 \omega 7 c$ and/or $18: 1 \omega 6 c)$.

The type strain, CCBAU $11299^{\mathrm{T}}\left(=\mathrm{LMG} 24397^{\mathrm{T}}=\mathrm{HAMBI}\right.$ $2990^{\mathrm{T}}$ ), was isolated from root nodules of Caragana microphylla growing in Beipiao city, Liaoning Province, China. The DNA $\mathrm{G}+\mathrm{C}$ content of the type strain is $59.7 \mathrm{~mol} \%\left(T_{\mathrm{m}}\right)$.

\section{Acknowledgements}

This work was financed by the National Natural Science Foundation of China (project no. 30400001 and 30670001), National Program for Basic S \& T Platform Construction (No. 2005DKA21201-10) and National Basic Research Program of China (2006CB100206, 2006AA10A213). We thank Professor J. P. Euzéby for his suggestion for the spelling of the specific epithet. We also thank Professor Janet Sprent and Professor Terry Godfrey for their embellishment of the manuscript.

\section{References}

Chen, W. X., Li, G. S., Qi, Y. L., Wang, E. T., Yuan, H. L. \& Li, J. L. (1991). Rhizobium huakuii sp. nov., isolated from the root nodules of Astragalus sinicus. Int J Syst Bacteriol 41, 275-280.

Chen, W. X., Wang, E. T., Wang, S. Y., Li, Y. B., Chen, X. O. \& Li, Y. (1995). Characteristics of Rhizobium tianshanense sp. nov., a moderately and slowly growing root nodule bacterium isolated from an arid saline environment in Xinjiang, People's Republic of China. Int J Syst Bacteriol 45, 153-159.

de Lajudie, P., Willems, A., Nick, G., Moreira, F., Molouba, F., Hoste, B., Torck, U., Neyra, M., Collins, M. D. \& other authors (1998). Characterization of tropical tree rhizobia and description of Mesorhizobium plurifarium sp. nov. Int J Syst Bacteriol 48, 369-382.
De Ley, J. (1970). Reexamination of the association between melting point, buoyant density, and chemical base composition of deoxyribonucleic acid. J Bacteriol 101, 738-754.

Felsenstein, J. (1985). Confidence limits on phylogenies: an approach using the bootstrap. Evolution 39, 783-791.

Gao, J. L., Sun, J. G., Li, Y., Wang, E. T. \& Chen, W. X. (1994). Numerical taxonomy and DNA relatedness of tropical rhizobia isolated from Hainan Province, China. Int J Syst Bacteriol 44, 151-158.

Gao, J. L., Terefework, Z., Chen, W. X. \& Lindström, K. (2001). Genetic diversity of rhizobia isolated from Astragalus adsurgens growing in different geographical regions of China. J Biotechnol 91, 155-168.

Gao, J. L., Turner, S. L., Kan, F. L., Wang, E. T., Tan, Z. Y., Qiu, Y. H., Gu, J., Terefework, Z., Young, J. P. \& other authors (2004). Mesorhizobium septentrionale sp. nov. and Mesorhizobium temperatum sp. nov. isolated from Astragalus adsurgens growing in the northern regions of China. Int J Syst Evol Microbiol 54, 2003-2012.

Gaunt, M. W., Turner, S. L., Rigottier-Gois, L., Lioyd-Macgilp, S. A. \& Young, J. P. W. (2001). Phylogenies of atpD and recA support the small subunit rRNA-based classification of rhizobia. Int J Syst Evol Microbiol 51, 2037-2048.

Ghosh, W. \& Roy, P. (2006). Mesorhizobium thiogangeticum sp. nov., a novel sulfur-oxidizing chemolithoautotroph from rhizosphere soil of an Indian tropical leguminous plant. Int J Syst Evol Microbiol 56, 91-97.

Jarvis, B. D. W., van Berkum, P., Chen, W. X., Nour, S. M., Fernandez, M. P., Cleyet-Marel, J. C. \& Gillis, M. (1997). Transfer of Rhizobium loti, Rhizobium huakuii, Rhizobium ciceri, Rhizobium mediterraneum, and Rhizobium tianshanense to Mesorhizobium gen. nov. Int J Syst Bacteriol 47, 895-898.

Jukes, T. H. \& Cantor, C. R. (1969). Evolution of protein molecules. In Mammalian Protein Metabolism, vol. 3, pp. 21-132. Edited by H. N. Munro. New York: Academic Press.

Laguerre, G., Nour, S. M., Macheret, V., Sanjuan, J., Drouin, P. \& Amarger, N. (2001). Classification of rhizobia based on nodC and nifH gene analysis reveals a close phylogenetic relationship among Phaseolus vulgaris symbionts. Microbiology 147, 981-993.

Marmur, J. (1961). A procedure for the isolation of deoxyribonucleic acid from microorganisms. J Mol Biol 3, 208-218.

Marmur, J. \& Doty, P. (1962). Determination of the base composition of deoxyribonucleic acid from its thermal denaturation temperature. $J$ Mol Biol 5, 109-118.

Martens, M., Dawyndt, P., Coopman, R., Gillis, M., De Vos, P. \& Willems, A. (2008). Advantages of multilocus sequence analysis for taxonomic studies: a case study using 10 housekeeping genes in the genus Ensifer (including former Sinorhizobium). Int J Syst Evol Microbiol 58, 200-214.

Nour, S. M., Fernandez, M. P., Normand, P. \& Cleyet-Marel, J.-C. (1994). Rhizobium ciceri sp. nov., consisting of strains that nodulate chickpeas (Cicer arietinum L.). Int J Syst Bacteriol 44, 511-522.

Nour, S. M., Cleyet-Marel, J.-C., Normand, P. \& Fernandez, M. P. (1995). Genomic heterogeneity of strains nodulating chickpeas (Cicer arietinum L.) and description of Rhizobium mediterraneum sp. nov. Int J Syst Bacteriol 45, 640-648.

Parker, M. A. (2004). rRNA and $d n a K$ relationships of Bradyrhizobium sp. nodule bacteria from four papilionoid legume trees in Costa Rica. Syst Appl Microbiol 27, 334-342.

Saitou, N. \& Nei, M. (1987). The neighbor-joining method: a new method for reconstructing phylogenetic trees. Mol Biol Evol 4, 406425.

Sasser, M. (1990). Identification of bacteria by gas chromatography of cellular fatty acids, MIDI Technical Note 101. Newark, DE: MIDI Inc. 
Schutter, M. E. \& Dick, R. P. (2000). Comparison of fatty acid methyl ester (FAME) methods for characterizing microbial communities. Soil Sci Soc Am J 64, 1659-1668.

Stepkowski, T., Czaplinska, M., Miedzinska, K. \& Moulin, L. (2003). The variable part of the $d n a K$ gene as an alternative marker for phylogenetic studies of rhizobia and related alpha Proteobacteria. Syst Appl Microbiol 26, 483-494.

Su, Y. Z., Zhang, T. H., Li, Y. L. \& Wang, F. (2005). Changes in soil properties after establishment of Artemisia halodendron and Caragana microphylla on shifting sand dunes in semiarid Horqin Sandy Land, northern China. Environ Manage 36, 272-281.

Tamura, K., Dudley, J., Nei, M. \& Kumar, S. (2007). MEGA4: Molecular evolutionary genetics analysis (MEGA) software version 4.0. Mol Biol Evol 24, 1596-1599.

Tan, Z. Y., Wang, E. T., Gao, J. L., Martínez-Romero, E. \& Chen, W. X. (1997). Phylogenetic and genetic relationships of Mesorhizobium tianshanense and related rhizobia. Int J Syst Bacteriol 47, 874-879.

Tighe, S. W., de Lajudie, P., Dipietro, K., Lindström, K., Nick, G. \& Jarvis, B. D. W. (2000). Analysis of cellular fatty acids and phenotypic relationships of Agrobacterium, Bradyrhizobium, Mesorhizobium, Rhizobium and Sinorhizobium species using the Sherlock Microbial Identification System. Int J Syst Evol Microbiol 50, 787-801.

Turner, S. L. \& Young, J. P. W. (2000). The glutamine synthetases of rhizobia: phylogenetics and evolutionary implications. Mol Biol Evol 17, 309-319.

Vauterin, L. \& Vauterin, P. (1992). Computer-aided objective comparison of electrophoresis patterns for grouping and identification of microorganisms. Eur Microbiol 1, 37-41.

Velázquez, E., Igual, J. M., Willems, A., Fernández, M. P., Muñoz, E., Mateos, P. F., Abril, A., Toro, N., Normand, P. \& other authors (2001). Mesorhizobium chacoense sp. nov., a novel species that nodulates
Prosopis alba in the Chaco Arido region (Argentina). Int J Syst Evol Microbiol 51, 1011-1021.

Vincent, J. M. (1970). The cultivation, isolation and maintenance of rhizobia. In A Manual for the Practical Study of the Root-Nodule Bacteria, pp. 1-13. Edited by J. M. Vincent. Oxford: Blackwell Scientific.

Vinuesa, P., León-Barrios, M., Silva, C., Willems, A., Jarabo-Lorenzo, A., Pérez-Galdona, R., Werner, D. \& Martínez-Romero, E. (2005). Bradyrhizobium canariense sp. nov., an acid-tolerant endosymbiont that nodulates endemic genistoid legumes (Papilionoideae: Genisteae) from the Canary Islands, along with Bradyrhizobium japonicum bv. genistearum, Bradyrhizobium genospecies $\alpha$ and Bradyrhizobium genospecies $\beta$. Int J Syst Evol Microbiol 55, 569-575.

Wang, E. T., van Berkum, P., Sui, X. H., Beyene, D., Chen, W. X. \& Martínez-Romero, E. (1999). Diversity of rhizobia associated with Amorpha fruticosa isolated from Chinese soils and description of Mesorhizobium amorphae sp. nov. Int J Syst Bacteriol 49, 51-65.

Wang, F. O., Wang, E. T., Liu, J., Chen, Q., Sui, X. H., Chen, W. F. \& Chen, W. X. (2007). Mesorhizobium albiziae sp. nov., a novel bacterium that nodulates Albizia kalkora in a subtropical region of China. Int J Syst Evol Microbiol 57, 1192-1199.

Wernegreen, J. J. \& Riley, M. A. (1999). Comparison of the evolutionary dynamics of symbiotic and housekeeping loci: a case for the genetic coherence of rhizobial lineages. Mol Biol Evol 16, 98113.

Xiang, T., Uno, T., Ogino, F., Ai, C., Duo, J. \& Sankawa, U. (2005). Antioxidant constituents of Caragana tibetica. Chem Pharm Bull (Tokyo) 53, 1204-1206.

Yan, X. R., Chen, W. F., Fu, J. F., Lu, Y. L., Xue, C. Y., Sui, X. H., Li, Y., Wang, E. T. \& Chen, W. X. (2007). Mesorhizobium spp. are the main microsymbionts of Caragana spp. grown in Liaoning Province of China. FEMS Microbiol Lett 271, 265-273. 